\title{
Pengaruh Kebiasaan Belajar, Persepsi Siswa tentang Fasilitas Belajar, dan Interaksi Sosial Teman Sebaya Terhadap Prestasi Belajar Siswa pada Mata Pelajaran Akutansi Kelas X1 IPS MAN 02 Batu
}

\author{
Rio Andria Saputra \\ Bety Nur Achadiyah \\ Universitas Negeri Malang
}

\begin{abstract}
This study aims to determine the effect of study habit, students' perceptions of learning facilities, and social peers interaction on student achievement in accounting subject. This research is an explanatory research. The population of this study is all eleventh grade students of Social Studies at MAN 02 Batu consisting of 132 students that was taken through proportional random sampling technique and using a sample of 57 students. Data collection method uses a questionnaire to measure learning habits, perceptions of students about learning facilities, and social interaction of peers, while the documentation aims to take the accounting learning achievement data. Analysis of the data uses multiple linear regression analysis to test the hypothesis by using the t-test with SPSS.22 for windows.
\end{abstract}

Keywords: Learning Habit, Perception, Learning Facility, Social Interaction, Peer, Learning Achievement.

\begin{abstract}
Abstrak: Penelitian ini bertujuan untuk mengetahui pengaruh kebiasaan belajar, persepsi siswa tentang fasilitas belajar, dan interaksi sosial teman sebaya terhadap prestasi belajar siswa pada mata pelajaran akuntansi. Penelitian ini tergolong dalam penelitian eksplanatori. Populasi penelitian ini adalah seluruh siswa kelas XI IPS MAN 02 Batu sejumlah 132 siswa dan dengan teknik proportional random sampling digunakan sampel sejumlah 57 siswa. Metode pengumpulan data menggunakan angket untuk mengukur kebiasaan belajar, persepsi siswa tentang fasilitas belajar, dan interaksi sosial teman sebaya, sedangkan dokumentasi untuk mengambil data prestasi belajar akuntansi. Analisis data yang digunakan adalah analisis regresi linier berganda dengan pengujian hipotesis menggunakan uji t dengan bantuan program SPSS 22 for windows.
\end{abstract}

Kata kunci: Kebiasaan Belajar, Persepsi, Fasilitas Belajar, Interaksi Sosial, Teman Sebaya, Prestasi Belajar.

Dalam kehidupan berbangsa dan bernegara, pendidikan memiliki peranan yang sangat penting, yaitu untuk menjamin kelangsungan kehidupan dan perkembangan bangsa itu sendiri. Pendidikan ditujukan untuk meningkatkan kualitas sumberdaya manusia. Hal tersebut sebagaimana tercantum dalam Undang-
Undang Nomor 20 Tahun 2003 tentang Sistem Pendidikan Nasional yang menyatakan bahwa pendidikan adalah usaha sadar dan terencana untuk mewujudkan suasana belajar dan proses pembelajaran agar peserta didik secara aktif mengembangkan potensi dirinya untuk memiliki kekuatan spiritual 
keagamaan, pengendalian diri, kebiasaan belajar dan cita-cita siswa. (b) kepribadian, kecerdasan, akhlak mulia, faktor eksternal belajar meliputi hal serta keterampilan yang diperlukan dirinya, masyarakat bangsa dan negara.

Belajar menurut Slameto (2010: 2) ialah suatu proses usaha yang dilakukan seseorang untuk memperoleh suatu perubahan tingkah laku yang baru secara keseluruhan, sebagai hasil pengalamannya sendiri dalam interaksi dengan lingkungannya. Lingkungan sendiri merupakan sesuatu yang mengelilingi individu, baik dalam bentuk lingkungan fisik seperti orang tua, rumah, kawan bermain, dan masyarakat sekitar, maupun dalam bentuk lingkungan psikologis seperti perasaan-perasaan yang dialami, cita-cita, persoalan-persoalan yang dihadapi (F. Patty dalam Baharudin 2007:68-69).

Ada beberapa faktor yang mempengaruhi siswa dalam mmahami dan menyerap ilmu. Menurut Dimyati (2006: 239-253), faktor-faktor yang mempengaruhi adalah: (a) faktor internal yang dialami dan dihayati oleh siswa meliputi hal-hal seperti: Sikap belajar, motivasi belajar, konsentrasi belajar, kemampuan mengelola bahan ajar, kemampuan menyimpan perolehan hasil belajar, menggali hasil belajar yang tersimpan, kemampuan berprestasi atau unjuk hasil belajar, rasa percaya diri siswa, intelegensi dan keberhasilan belajar, sebagai berikut: guru sebagai pembina siswa belajar, sarana dan prasarana pembelajaran, kebijakan penilaian, lingkungan sosial siswa di sekolah dan kurikulum sekolah.

Salah satu faktor internal dalam diri siswa adalah kebiasaan belajar. Teori cognitive development yang dikemukakan oleh Piaget (Suparno, 2001: 20), mengungkapkan bahwa intelegensi seseorang terdiri dari tiga aspek yaitu struktur (pola tingkah laku yang dapat diulang), isi (pola tingkah laku yang spesifik), dan fungsi (berhubungan dengan cara seseorang mencapai kemajuan intelektual). Dalam aspek struktur merupakan pola tingkah laku yang dapat diulang. Pola tingkah laku yang dilakukan secara terus menerus secara rutin dan teratur sehingga disebut dengan kebiasaan. Kebiasaan belajar merupakan persoalan setiap siswa. Mereka memiliki kebiasaan belajar yang khas yang disesuaikan dengan selera dan kondisi masing-masing individu. Berbagai kebiasaan dapat berupa cara mereka dalam mempelajari materi suatu pelajaran, kebiasaan istirahat sejenak pada saat belajar, keteraturan dalam belajar, mendengarkan musik saat belajar, dan sebagainya. Kebiasaan mempelajari suatu materi pelajaran antara siswa satu dengan siswa berbeda-beda. Ada siswa 
yang biasa mempelajari materi pelajaran dengan cara menghafal, ada pula siswa yang lebih menyukai dengan memusatkan perhatiannya pada pengertian atau pemecahan masalah.

$$
\text { Selain faktor intern yang }
$$
berpengaruh terhadap proses belajar dan prestasi belajar siswa, terdapat juga faktor ekstern. Antara lain fasilitas belajar dan interaksi sosial teman sebaya. Fasilitas dalam dunia pendidikan berarti segala sesuatu yang bersifat fisik maupun material, yang dapat memudahkan terselenggaranya proses belajar mengajar. Menurut Badafal (2003:86), “fasilitas pembelajaran mencakup sarana dan prasarana sekolah. Sarana pendidikan merupakan semua perangkat peralatan, bahan dan perabotan yang secara langsung digunakan dalam proses pendidikan sekolah. Sedangkan prasaran pendidikan adalah semua perangkat kelengkapan dasar yang tidak langsung menunjang pelaksaan proses pendidikan di sekolah. Hal tersebut sejalan dengan yang dikemukakan oleh Sanjaya (2011:18) sarana adalah segala sesuatu yang mendukung secara langsung terhadap kelancaran proses pembelajaran, alat-alat pelajaran, perlengkapan sekolah, dan lain sebagainya. Prasarana adalah segala sesuatu yang secara tidak langsung dapat mendukung keberhasilan proses pembelajaran misalnya jalan menuju sekolah, penerangan sekolah, kamar kecil dan lain sebagainya.

Adapun faktor ekstern lain yaitu interaksi sosial siswa dengan teman sebaya. Teori hasil interaksi (Interaction Outcome Theory) yang dikemukakan oleh Thibaut \& Kelly, menerangkan bahwa hubungan dua orang (atau lebih) di mana saling tergantung untuk mencapai hasilhasil positif. Menurut Ahmadi (2009: 49), interaksi sosial adalah suatu hubungan dua orang atau lebih, dimana tingkah laku yang satu mempengaruh dan memperbaiki kelakuan individu lain atau sebaliknya. Hal tersebut hampir sama dengan yang dikemukakan oleh Ali dan Asrori (2004: 87), interaksi sosial sebagai peristiwa saling mempengaruhi satu sama lainnya ketika dua orang atau lebih hadir bersama, mereka menciptakan suatu hasil satu sama lain atau berkomunikasi satu sama lain. Berdasarkan uraian di atas dapat diketahui bahwa lingkungan sangat berpengaruh dalam kehidupan manusia, terutama lingkungan sosial dalam masyarakat. Lingkungan sekolah, lingkungan belajar, lingkungan keluarga, lingkungan teman sebaya juga mempunyai pengaruh yang besar terhadap keberhasilan seseorang dalam mencapai tujuannya.

\section{METODE}

Penelitian ini digolongkan menjadi penelitian penjelasan atau explanatory 
research. Penelitian explanasi (Explanatory Research) adalah penelitian yang menjelaskan pengaruh dan hubungan kausal antara variabel-variabel melalui pengujian hipotesis. Pendekatan yang digunakan dalam penelitian ini adalah pendekatan kuantitatif yang bertujuan menguji pengaruh kebiasaan belajar (X1), persepsi siswa tentang fasilitas belajar (X2), dan interaksi sosial teman sebaya (X3) terhadap hasil belajar siswa (Y). Pendekatan ini didasarkan pada data yang diperlukan dalam penelitian ini berupa data yang bersifat kuantitatif yang diperoleh memalui kuisioner dan dari nilai mata pelajaran akuntansi.

Populasi dalam penelitian ini adalah seluruh siswa kelas XI IPS MAN 02 Batu dengan jumlah siswa 132 siswa. Teknik pengambilan sampel yang digunakan dalam penelitian ini adalah sampel proporsi atau proportional random samping, yaitu untuk memperoleh sampel yang representatif, pengambilan subjek dari setiap kelas ditentukan seimbang atau sebanding dengan banyaknya subjek dalam masing-masing kelas. Dengan populasi sebesar 132 siswa dan tingkat kelonggaran ketidaktelitian sebesar $10 \%$ maka jumlah sampel yang diperoleh yaitu 57 siswa.

Instrumen yang digunakan dalam penelitian ini adalah berupa angket, dimana responden akan diminta untuk mengisi pertanyaan atau pernyataan dalam angket tersebut dengan maksud untuk memperoleh data mentah dari responden yang mengisi data tersebut. Angket ini digunakan untuk mengukur variabel kebiasaan belajar, persepsi siswa tentang fasilitas belajar, dan interaksi sosial teman sebaya. Sedangkan, dokumen digunakan untuk mengumpulkan data prestasi belajar. Analisis data yang digunakan adalah analisis deskriptif dengan model sebagai berikut.

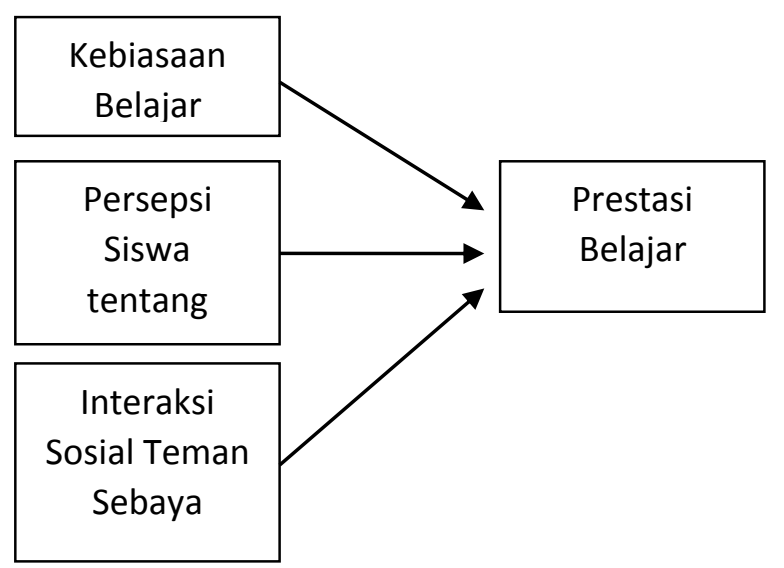

Variabel - variabel yang akan diteliti yaitu :

(X1): Kebiasaan Belajar

(X2): Persepsi Siswa tentang Fasilitas Belajar

(X3): Interaksi Sosial Teman Sebaya

(Y): Prestasi Belajar

\section{HASIL PENELITIAN}

Pengaruh Kebiasaan Belajar terhadap

Prestasi Belajar pada Mata Pelajaran

Akuntansi Siswa Kelas XI IPS MAN 02

Batu.

Dari hasil analisis data, pada variabel kebiasaan belajar dapat dilihat bahwa besaran probabilitas (Sig.) 0,001 < 
0,05 , dan thitung $(3,697)>\operatorname{ttabel}(2,005)$.

Hal ini membuktikan bahwa terdapat pengaruh yang signifikan antara kebiasaan belajar dengan prestasi belajar siswa. Oleh karena itu $\mathrm{H} 1$ yang menyatakan bahwa ada pengaruh positif antara kebiasaan belajar dengan prestasi belajar siswa diterima. Sebaliknya HO yang menyatakan bahwa tidak ada pengaruh antara kebiasaan belajar terhadap prestasi belajar siswa ditolak.

\section{Pengaruh Persepsi Siswa tentang} Fasilitas Belajar pada Mata Pelajaran Akuntansi Siswa Kelas XI IPS MAN 02 Batu

Dari hasil analisis data, pada variabel persepsi siswa tentang fasilitas belajar dapat dilihat bahwa besaran probabilitas (Sig.) 0,014 < 0,05, dan thitung $(2,538)>\operatorname{ttabel}(2,005)$. Hal ini membuktikan bahwa terdapat pengaruh yang signifikan antara persepsi siswa tentang fasilitas belajar dengan prestasi belajar siswa. Oleh karena itu H1 yang menyatakan bahwa ada pengaruh positif antara persepsi siswa tentang fasilitas belajar dengan prestasi belajar siswa diterima. Sebaliknya H0 yang menyatakan bahwa tidak ada pengaruh antara persepsi siswa tentang fasilitas belajar terhadap prestasi belajar siswa ditolak.
Pengaruh Interaksi Sosial Teman Sebaya terhadap Prestasi Belajar pada Mata Pelajaran Akuntansi Siswa Kelas XI IPS MAN 02 Batu

Dari hasil analisis data, pada variabel persepsi siswa tentang fasilitas belajar dapat dilihat bahwa besaran probabilitas (Sig.) 0,001 < 0,05, dan thitung $(3,477)>\operatorname{ttabel}(2,005)$. Hal ini membuktikan bahwa terdapat pengaruh yang signifikan antara interaksi sosial teman sebaya dengan prestasi belajar siswa. Oleh karena itu H1 yang menyatakan bahwa ada pengaruh positif antara interaksi sosial teman sebaya dengan prestasi belajar siswa diterima. Sebaliknya H0 yang menyatakan bahwa tidak ada pengaruh antara interaksi sosial teman sebaya terhadap prestasi belajar siswa ditolak.

\section{PEMBAHASAN}

Pengaruh Kebiasaan Belajar terhadap Prestasi Belajar

Hasil penelitian menunjukkan bahwa kebiasaan belajar siswa di MAN 02 Batu tergolong cukup baik karena mereka memiliki kedisiplinan belajar, pemantapan materi belajar serta kesiapan menghadapi tes yang cukup baik, sehingga prestasi belajar pun baik. Dari data yang peneliti peroleh sebanyak 57 siswa yang diteliti, 20 siswa (35\%) beranggapan bahwa kebiasaan belajar siswa sangat baik, dan 
37 siswa $(65 \%)$ beranggapan bahwa kebiasaan belajar siswa baik. Berdasarkan hasil tersebut dapat diketahui bahwa kebiasaan belajar siswa di MAN 02 Batu tergolong baik. Jadi semakin baik kebiasaan belajar siswa maka prestasi belajar siswa pun akan semakin baik.

Kebiasaan belajar merupakan variabel yang perlu diperhatikan dalam usaha mencapai hasil belajar yang memuaskan. Kebiasaan sebagai suatu yang telah dilakukan seseorang secara berulangulang dan telah menjadi ciri dari seseorang, sehingga kebiasaan cenderung bersifat relatif tetap dan sulit untuk dirubah. Hasil penelitian ini relevan dengan pernyataan menurut Gie (1988: 78), "kebiasan belajar adalah perilaku seseorang yang dilakukan secara tetap atau sama dari waktu ke waktu tanpa pemakaian banyak pikiran". Dengan adanya kebiasaan belajar dapat mendorong seseorang untuk lebih giat memperluas pengetahuannya. Semakin tinggi kebiasaan belajar pada diri seseorang maka semakin tinggi pula hasil belajar yang diterimanya sehingga diharapkan dapat mencapai tujuan belajar yang optimal. Sedangkan menurut teori cognitive development yang dikemukakan oleh Piaget , mengungkapkan bahwa intelegensi seseorang terdiri dari tiga aspek, yaitu struktur (pola tingkah laku yang dapat diulang), isi (pola tingkah laku yang spesifik), dan fungsi (berhubungan dengan cara seseorang mencapai kemajuan intelektual). Salah satu aspek intelegensi adalah pola tingkah laku yang dapat diulang, dalam hal ini adalah kebiasaan belajar. Jika aspek ini dihubungkan dengan aspek yang terakhir yaitu fungsi, maka dapat dikatakan kebiasaan belajar merupakan suatu cara untuk mencapai kemajuan intelektual. Kemajuan intelektual yang tercapai dapat menghasilkan output berupa prestasi belajar yang baik.

Hasil penelitian terdahulu yang relevan dengan penelitian ini dilakukan oleh Nur Khasanah (2011) yang berjudul "Pengaruh Kebiasaan Belajar, Kepercayaan Diri Siswa, dan Lingkungan Keluarga terhadap Hasil Belajar Mata Pelajaran Akutansi (SMA Negeri 1 Sumberpucung Kabupaten Malang)", yang menyebutkan bahwa terdapat pengaruh signifikan kebiasaan belajar terhadap prestasi belajar siswa. Berdasarkan hasil di atas maka dapat di simpulkan bahwa kebiasaan belajar memang memiliki pengaruh terhadap prestasi belajar.

Dengan demikian kebiasaan belajar yang tinggi maka siswa dapat meningkatkan prestasi belajarnya. Setiap kebiasaan belajar yang dimiliki akan mendorongnya untuk melakukan usaha dalam belajar untuk mencapai prestasi yang optimal. Dengan adanya usaha yang 
tekun dan didasari adanya kebiasaan belajar, maka seseorang yang belajar akan dapat melahirkan prestasi yang baik.

\section{Pengaruh Persepsi Siswa tentang Fasilitas Belajar terhadap Prestasi Belajar}

Berdasarkan hasil analisis yang telah dilakukan, persepsi siswa tentang fasilitas belajar di sekolah yang dilakukan oleh siswa kelas XI MAN 02 Batu menunjukkan bahwa pemanfaatan dan ketersediaan fasilitas belajar di sekolah yang dilakukan cukup tinggi. Sebanyak 15 siswa $(26 \%)$ beranggapan bahwa fasilitas belajar siswa sangat baik, 30 siswa (53\%) beranggapan bahwa fasilitas belajar siswa baik, dan 12 siswa (21\%) beranggapan bahwa fasilitas belajar siswa cukup baik. Siswa yang menggunakan fasilitas belajar belajar di sekolah yang baik besar kemungkinannya untuk mendapatkan prestasi belajar yang memuaskan.

Hasil penelitian ini sejalan dengan pernyataan menurut Bafadal (2003:86), "fasilitas belajar yang tersedia dalam jumlah memadai di suatu sekolah atau lembaga pendidikan juga memberikan sumbangan yang besar dalam membantu memfasilitasi guru dan peserta didik atau di tempat belajar lainnya dalam menyukseskan proses belajar mengajar.
Tanpa ada fasilitas belajar yang tersedia dalam jumlah yang memadai di sekolah, proses interaksi belajar mengajar antara guru dan siswa kurang dapat berjalan dengan optimal". Sedangkan menurut teori belajar behavioristik yang dikemukakan oleh Gage \& Berliner, menjelaskan bahwa belajar merupakan akibat adanya interaksi antara stimulus dan respon (Slavin, 2000:143). Dengan memberikan stimulus berupa fasilitas belajar yang memadai, siswa akan merasa lebih nyaman dalam proses belajar mengajar. Kenyamanan siswa dalam belajar akan berpengaruh terhadap prestasi belajarnya. Sehubungan dengan hal tersebut maka pengadaan sarana dan prasarana sekolah perlu diperhatikan agar siswa merasa diperhatikan dan merasa nyaman belajar disekolah.

\section{Pengaruh Interaksi Sosial Teman} Sebaya terhadap Prestasi Belajar Siswa

Berdasarkan hasil analisis yang telah dilakukan pada siswa kelas XI MAN 02 Batu menunjukkan bahwa interaksi sosial dengan teman cukup tinggi. Sebanyak 33\% (19 siswa) beranggapan bahwa interaksi sosial siswa sangat baik, $58 \%$ (33 siswa) beranggapan bahwa interaksi sosial siswa baik, dan 9\% (5 siswa) beranggapan bahwa interaksi sosial siswa cukup baik. Siswa yang memiliki interaksi sosial yang baik dengan teman 
sebayanya besar kemungkinannya untuk mendapatkan prestasi belajar yang memuaskan. Dengan melakukan interaksi sosial yang baik seorang siswa akan terdorong memiliki jiwa kerja sama yang baik jika dibandingkan dengan siswa yang tidak dapat melakukan interaksi sosial dengan teman sebayanya yang cenderung menyendiri dan memiliki sifat individualisme yang tinggi.

Hasil penelitian ini relevan sesuai dengan pendapat Syah (2006:144) yang menyatakan bahwa bahwa prestasi belajar dipengaruhi oleh lingkungan teman sebayanya yaitu antara lain pengaruh relasi dengan teman sebaya. Sedangkan teori hasil interaksi (interaction outcome theory) dari Thibaut \& Kelley (1959), yang menerangkan bahwa hubungan dua orang (atau lebih) di mana mereka saling tergantung untuk mencapai hasil-hasil positif. Interaksi sosial yang saling tergantung bertujuan untuk memaksimalkan hasil yang positif bagi tiap-tiap peserta interaksi. Interaksi yang mencapai hasil yang positif diperoleh melalui proses interaksi antar teman sebaya ketika siswa saling bekerja sama, bersaing, dan mencontoh figure yang baik dalam rangka meningkatkan prestasi belajar yang baik. Hasil positif dalam hal ini dapat dilihat dari prestasi belajar. Fungsi memaksimalkan hasil yang positif berlaku juga untuk seluruh kelompok sehingga individu-individu sebagai kelompok dapat tetap bersatu.

\section{SIMPULAN}

Berdasarkan hasil analisis terkait dengan rumusan masalah dalam penelitian ini, maka kesimpulan dapat dirumuskan sebagai berikut.

1. Terdapat pengaruh positif signifikan kebiasaan belajar terhadap prestasi belajar akuntansi siswa Kelas XI IPS MAN 02 Batu. Hal ini berarti jika kebiasaan belajar yang dimiliki oleh siswa meningkat, maka prestasi belajar juga akan meningkat dan berlaku sebaliknya.

2. Terdapat pengaruh positif signifikan persepsi siswa tentang fasilitas belajar terhadap kebiasaan belajar siswa Kelas XI IPS MAN 02 Batu. Hal ini berarti jika semakin baik siswa memanfaatkan fasilitas belajar, maka prestasi belajar juga akan meningkat dan berlaku sebaliknya

3. Terdapat pengaruh positif signifikan interaksi sosial teman sebaya terhadap prestasi belajar akuntansi siswa Kelas XI IPS MAN 02 Batu. Hal ini berarti semakin baik (positif) interaksi sosial 
teman sebaya, maka semakin baik pula prestasi belajarnya dan berlaku sebaliknya.

Penelitian ini memiliki keterbatasan meskipun telah melakukan uji validitas dan reabilitas instrumen, pengumpulan melalui angket ini masih ada kelemahankelemahan seperti jawaban yang kurang cermat, responden yang menjawab asalasalan dan tidak jujur.

Dengan memperhatikan hasil temuan dalam penelitian ini, maka dalam kesempatan ini penulis bermaksud menyampaikan saran-saran dengan harapan agar memiliki kemanfaatan yang berarti bagi banyak pihak. Saran dari penelitian ini sebaiknya menggunakan sampel yang lebih luas dengan wilayah populasi yang besar sehingga diharapkan akan mengungkap lebih banyak permasalahan dan memberikan hasil temuan penelitian yang lebih berarti bagi banyak pihak. Selain itu untuk penelitian selanjutnya yang berminat melakukan penelitian dengan topik yang sama diharapkan mengkombinasikan pengumpulan data berupa angket dengan teknik wawancara dan observasi atau eksperimen.

\section{DAFTAR RUJUKAN}

Ahmadi, Abu. 1993. Cara Belajar yang Mandiri dan Sukses. Solo: Anaka.

Ali, Moh dan Asrori, Moh, 2004. Psikologi Remaja. Jakarta: Bumi Aksara.

Arikunto, Suharsimi. 2002. Prosedur Penelitian Suatu Pendidikan Praktek. Jakarta: Rineka Cipta

Penelitian Suatu Pendekatan Praktik (Edisi revisi VI). Jakarta: PT Rineka Cipta.

Aunurahman. 2009. Belajar dan Pembelajaran. Bandung: Alfabeta.

Bafadal, Ibrahim. 2008. Manajemen Perlengkapan Sekolah Teori dan Aplikasinya. Jakarta: Bumi Aksara.

Baharudin. 2007. Psikologi Pendidikan. Jogjakarta: Ar-Ruzz Media.

Departemen Pendidikan Nasional Republik Indonesia. 2008. Kamus Besar Bahasa Indonesia. Jakarta: Gramedia Pustaka Utama.

Dimyati \& Mudjiono. 2000. Belajar dan Pembelajaran. Jakarta: PT Asdi Mahasatya.

Dimyati \& Mudjiono. 2006. Belajar dan Pembelajaran. Jakarta: Rineka Cipta.

Djamarah, Syaiful Bahri.2002. Psikologi Belajar. Jakarta : Rineka Cipta

Gerungan, WA, 2000. Psikologi Sosial. Bandung: Refika Aditama.

Ghozali, Imam. 2007. Aplikasi Analisis Multivariate bagi Program SPSS. Semarang: UNDIP

Gie, The Liang. 1988. Cara Belajar yang Efisien. Yogyakarta: Pusat Kemajuan Studi. 
1995. Cara belajar yang Efisien Jilid II. Yogyakarta: Liberty

Goldberg, Alvin A. 1985. Komunikasi kelompok : proses-proses diskusi dan penerapannya. Jakarta : UIPerss

Hurlock, Elizabeth. 1980. Psikologi Perkembangan : Suatu Pendekatan Sepanjang Rentang Kehidupan. Jakarta : Erlangga.

Hurlock, Elizabeth. 2002. Perkembangan Anak Jilid II. Jakarta: Gunung ULya.

Irawati, Novita. 2012. Pengaruh Interaksi Sosial Teman Sebaya Dan Tingkat Kedisiplinan Siswa Terhadap Prestasi Belajar Akuntansi Siswa SMA Negeri 1 Kauman Tulungagung. Skripsi tidak diterbitkan. Malang: Universitas Negeri Malang.

Khasanah, Nur. 2011, Pengaruh Kebiasaan Belajar, Kepercayaan Diri Siswa, dan Lingkungan Keluarga terhadap Hasil Belajar Mata Pelajaran Akutansi (SMA Negeri $1 \quad$ Sumberpucung Kabupaten Malang. Skripsi tidak diterbitkan. Malang: Universitas Negeri Malang.

Leung, M. Y and Fung, I. 2005. Enhancement of classroom facilities of primary schools and its impact on learning behaviors of students. (online), (http://www.emeraldinsight.com/In sight/ViewContentServlet?content Type

$=$ Article $\&$ Filename $=$ Published $/$ Em eraldFullTextArticle/Articles/1060 2105

05.html, diakses 20 September 2014).
Nurmalia, Erlina. 2010. Pengaruh Fasilitas, dan Lingkungan Belajar Terhadap Prestasi Belajar Siswa Kelas XI IPS MAN 1. Skripsi tidak diterbitkan. Malang: Universitas Negeri Malang.

Mudjiyono,dan Dimyati.2002.Belajar dan Pembelajaran.Jakarta:PT.Rineka Cipta

Purwanto. 2011. Evaluasi Hasil Belajar. Yogyakarta: Pustaka Pelajar.

Purwanto, Ngalim. 2007. Ilmu Pendidikan Teoritis dan Praktik. Bandung: PT Remaja Rosdakarya.

Purwanto, Ngalim. 2007. Psikologi Pendidikan. Bandung: Remaja Rosdakarya.

Sardiman, AM.2006. Interaksi dan Motivasi Belajr Mengajar. Jakarta : Raja Grafindo Persada

Sanjaya, Wina. 2011. Perencanaan dan Desain Sistem Pembelajran. Jakarta: Kencana.

Sarwono, Jonathan. 2006. Metode penelitian kuantitatif dan kualitatif. Bandung: Graha ilmu.

Slavin, Robert E. 2011. Psikologi Pendidikan Teori dan Praktik Edisi Kesembilan Jilid 1. Jakarta: PT. Indeks.

Slameto. 2003. Belajar dan Faktor-faktor yang Mempengaruhinya. Jakarta: Rineka Cipta.

Soekanto. S. (1990). Sosiologi Suatu Pengantar. Jakarta: Raja Grafindo.

Suparno, P. 2001. Teori Perkembangan Kognitif Jean Piaget. Yogyakarta: Kanisius.

Sudarsono, 1997, Kamus Konseling. Jakarta: Rineka Cipta. 
Sudarmanto, R Gunawan. 2005. Analaisis Regresi Linier Berganda dengan SPSS.Yogjakarta: Graha Ilmu

Sudjana, Nana. 1990. Penilaian Hasil Proses Belajar Mengajar. Bandung : Remaja Rosda Karya

Sudjana, Nana. 2005. Dasar-dasar Proses Belajar Mengajar. Bandung: Sinar Baru Algasindo.

Sugiyono. 2009. Metode Penelitian Kuantitatif Kualitatif dan $R \& D$. Bandung: Alfabeta

Sugiyono.2008.Metode Penelitian Pendidikan.Bandung:CV.Alfabeta

Suryabrata, Sumadi. 2008. Psikologi Pendidikan. Jakarta: PT Raja Grafindo Persada.

Syah, Muhibbin. 2008. Psikologi Pendidikan dengan Pendidikan Baru EdisiRevisi. Bandung: PT Remaja Rosda Karya.

Syah, Muhibbin.1999. Psikologi Belajar. Jakarta: Logos

Tim Dosen Jurusan Admnistrasi Pendidikan FIP IKIP Malang. 1989. Administrasi Pendidikan. Malang: IKIP Malang.

Universitas Negeri Malang. 2010. Pedoman Penulisan Karya Ilmiah: Skripsi, Tesis, Disertasi, Artikel, Makalah, Laporan Penelitian. Edisi Kelima Cetakan Kedua. Malang: Biro Administrasi Akademik, Perencanaan, dan Sistem Informasi bekerja sama dengan Penerbit Universitas Negeri Malang.

Winkel, W.S. 2005. Psikologi Pengajaran. Yogyakarta: Media Abdi. 